\title{
Fracture toughness of steel adherend bonded with two-part polyurethane adhesives: Double cantilever beam tests under static loading
}

\author{
Yuki Ogawa ${ }^{1}$, Kimiyoshi Naito ${ }^{2}$, Keisuke Harada ${ }^{3}$, and Hiroyuki OGUMA ${ }^{4}$ \\ ${ }^{1}$ Kobe University \\ ${ }^{2}$ National Institute for Materials Science (NIMS) \\ ${ }^{3}$ Acquisition Technology and Logistics Agency Naval Systems Research Center \\ ${ }^{4}$ National Institute for Materials Science
}

October 30, 2020

\begin{abstract}
The ductile structural adhesives such as a polyurethane adhesive are developed in recent years. This study is intended to measure the fracture toughness under Mode I loading of two-part polyurethane adhesives using double cantilever beam (DCB) tests. Two types of polyurethane adhesives and the effect of adhesive thickness on the fracture toughness are discussed. Plastic deformation of the steel adherends occurred in both adhesives for both adhesive types and thicknesses. Therefore, the arrest load out of consideration of a plastic deformation was evaluated the fracture toughness of the DCB specimens. As a result, the fracture toughness of the polyurethane adhesive is higher for higher tensile modulus and adhesive strength. In addition, the fracture toughness is higher for a larger adhesive thickness. The analytical results based on the triangle cohesive zone model using zero-thickness cohesive elements are agreed with the experimental results.
\end{abstract}

\section{Hosted file}

Manuscript.pdf available at https://authorea.com/users/371644/articles/489892-fracturetoughness-of-steel-adherend-bonded-with-two-part-polyurethane-adhesives-doublecantilever-beam-tests-under-static-loading

\section{Hosted file}

Table 1.pdf available at https://authorea.com/users/371644/articles/489892-fracturetoughness-of-steel-adherend-bonded-with-two-part-polyurethane-adhesives-doublecantilever-beam-tests-under-static-loading

\section{Hosted file}

Table 2.pdf available at https://authorea.com/users/371644/articles/489892-fracturetoughness-of-steel-adherend-bonded-with-two-part-polyurethane-adhesives-doublecantilever-beam-tests-under-static-loading

\section{Hosted file}

Table 3.pdf available at https://authorea.com/users/371644/articles/489892-fracturetoughness-of-steel-adherend-bonded-with-two-part-polyurethane-adhesives-doublecantilever-beam-tests-under-static-loading 


\section{Hosted file}

FFEMS Figure.pptx available at https://authorea.com/users/371644/articles/489892-fracturetoughness-of-steel-adherend-bonded-with-two-part-polyurethane-adhesives-doublecantilever-beam-tests-under-static-loading 